\title{
STUDIES OF SEED PROTEIN, ESTERASE ISOZYME AND SEED COAT SCAN ON SOME CULTIVATED SPECIES OF GENUS MINUSOPS (SAPOTACEAE) IN EGYPT
}

\author{
WAEL TAHA KASEEM and MAHMOUD A. MONSOUR \\ Botany and Microbiology Department, Faculty of Science, Al- Azhar University., \\ Madient Nasr, Cairo, Egypt.
}

\begin{abstract}
Electrophoretic profiles of native seed protein and esterase isozyme characters of four species of genus Mimusops have been revealed by PAGE. Seed coat scanning and numerical analysis of the results carried out. These species are M. laurifolia, M. elengi, M. zeyheri and M. coffra. The results of SEM on the surface seeds showed that, Seed ornamentation in Mimusops zeyheri differs than the rest species of the genus Mimusops by showing replicas of freeze on the their membrane surface. The results of seed protein and esterase isozyme characters indicated that delimitation of Mimusops zeyheri in a separated level, separation of two species of Mimusops coffra and Mimusops elengi in a separated group, in addition distinguishing of Mimusops laurifolia than other two species of Mimusops elengi and Mimusops coffra.
\end{abstract}

\section{Introduction}

Genus Mimusops belong to Tribe Mimusopeae of family Sapotaceae which have 53 genera and more than 1200 species (Govaerts et al., 2001). They occur worldwide, but mostly in tropical and subtropical regions (Igor et al., 2004). Genus Mimusops comprises about 30 species of which approximately 25 species are distributed in tropical regions of the world (Nusrat et al., 1995). The characters of the seed surface are often stable and comparative scanning electron microscopy of seed epidermal patterns and structure have provided useful taxonomic characters, especially in small seeds (Barthlott, 1981). Protein bands of family Sapotaceae have shown similar characteristics as molecular masses, determined by gel filtration and native gel. (Podrigues et al., 2004). Most useful methods for determination of the seed protein and isozymes are polyacrylamide and starch gel electrophoresis (Blakshear, 1984 and Zimniak-Przbylska et al., 1985). The use of seed profiles for taxonomic and evolutionary purposes has largely increased and has been widely used to many families and genera (Adrianse et al., 1969). Peptidase acid phosphates and peroxidases were unstable enzyme systems for comparative studies of extracted 
dry cotyledons, while esterase has been found stable for comparison (Ladizinsiky and Hymowitz, 1979). The present work has been carried out on the cultivated species of genus Mimusops in order to consideration the molecular pattern and studies a survey on the significance of macromorphological diagnostics attributes to clarify the interrelationships between the different species of genus Mimusops in Egypt.

\section{Materials and Methods}

In the present study, seeds of four species related to genus Mimusops have been investigated. Fruit specimens were collected from different botanical gardens in Egypt. A list of the studied taxa and localities are given in is Table 1.

\section{Table 1: Sources of the Studied Species:}

\begin{tabular}{|c|l|l|}
\hline No. & \multicolumn{1}{|c|}{ Taxa } & \multicolumn{1}{|c|}{ Location } \\
\hline 1 - & Mimusops laurifolia (Forssk.) Friis & El-Mesala Garden \\
2 - & Mimusops elengi Linn. & Orman Garden \\
3 - & Mimusops zeyheri Sond. & Orman Garden \\
$4-$ & Mimusops coffra DC. & El-Zohrya Garden \\
\hline
\end{tabular}

\section{A- Seed Coat Studies:}

For preparation of seeds of each specimens to scan the surface by using the Scanning Electron Microscope (SEM), the seeds were washed thoroughly by distilled water to remove any impurities on their surfaces dried and mounted on adhesive surface. These clean dry seeds were coated with gold film in Apolarom E 1100 ion sputtering device then viewed and photographed with Joel ISM 5300 scanning electron microscope in Ain Shams University.

\section{B- Electrophoretic Investigations:}

\section{1- Seed Protein Characters:}

Characterization of seed protein fraction was carried out by using one dimensional sodium dodecyl sulphate polyacrylamide gel electrophoresis (SDSPAGE) $0.5 \mathrm{~g}$ of mature dried seeds were mixed with an equal weight of pure, clean, sterile fine sand and powdered using a mortar and pestle. The powder was homogenized with $5 \mathrm{ml}$ of $0.2 \mathrm{M}$ Tris- $\mathrm{HCl}$ buffer $\mathrm{pH} 8$ for $\mathrm{I} \mathrm{h}$ at $4 \mathrm{oC}$, by gentle motion. The extract was centrifuged at $12000 \mathrm{rpm}$ for $10 \mathrm{~min}$. The supernatant( protein extract) was either immediately used or stored at $-20 \mathrm{oC}$. According to the methods described by Stegeman et al., (1988) the sample was prepared for 
electrophoresis as the following: To sample protein $20 \mu \mathrm{m}$ of each protein extract, $60 \mu \mathrm{m}$ of buffer, $50 \mu \mathrm{m}$ SDS ad $25 \mu \mathrm{m}$ mercaptoethanol were added and put and put in boiling water bath for 5 minutes. Then, $20 \mu$ of this mixture were loaded in $12.5 \%$ stacking gel, which was prepared as described by Laemmli(1970). Electrophoresis was carried out in Tris- Glycin buffer ( $\mathrm{pH} \mathrm{8.3)} \mathrm{at} \mathrm{4oC} \mathrm{and} 100$ volt for 2-3hr, untile tha tracking dye (bromophenol blue) reaches the bottom of the gel (Shi and Jackowski, 1998). The separated proteins bands were stained with coomassie brilliant blue stain R- $250(0.1 \mathrm{~g})$, distilled water $(400 \mathrm{ml})$, acetic acid $(70 \mathrm{ml})$, methanol $(200 \mathrm{ml})$ and trichloroacetic acid (TCA,60 ml)). The gels were soaked in excess of staining solution till the appearance of the bands, then, the gel was transferred to distaining solution (methanol, $150 \mathrm{ml})$, glacial acetic acid $(50 \mathrm{ml})$ distilled water $(300 \mathrm{ml})$. The bands produced by each sample were counted and their relatives mobilities were determined and scanned by using Hoefer Scanning Densitometer GS 300.

\section{2- Esterase Isozyme Character:}

$1 \mathrm{~g}$ seedlings was macerated in saline buffer solution $(0.8 \% \mathrm{NaCl}$ and $2.2 \%$ NaNO3) and centrifuged at 3000 r.p.m. for 3 minutes to prepare the crude tissues extract (7.5\% non-dissociating polyacrlamide gels). Also gels were prepared as described by Laemmli (1970). Esterase bands were detected after incubation in 100 $\mathrm{ml}$ of 0.1 phospate buffer tris buffer ( $\mathrm{pH} 7.5$ ), containing $0.02 \mathrm{~g} \alpha$ - naphthyl acetate and $0.02 \mathrm{~g} \beta$-naphthyl acetate dissolved in $2 \mathrm{ml}$ acetone, as substrate, and $0.15 \mathrm{~g}$ of fast blue R R, the gel was transferred to the distaining solution $(150 \mathrm{ml}$ methanol + $50 \mathrm{ml}$ glacial acetic acid $+30 \mathrm{ml}$ water). The bands produced by each sample were counted and their relatives motilities were determined and scanned by using Hoefer Scanning Densitometer GS 300.

\section{C- Numerical Analysis:}

Use of substantial number of attributes i. e. seed coat and electrophoretic investigations for all species have made it possible to produce a number of phenetic classifications based on the dissimilarity between genera and species. The character was treated as binary character in data matrix i. e. coded 1 and o respectively. For the numerical analysis the NTSYS-PC version 1.50 program was used (Rohlf, 1988). Clustering was performed using the unweighed pair-group method arithmetic means (UPGMA) by sequential, agglomerate, herarechial and nested clustering method (SAHN) as defined by Sneath and Sokal (1973). The output of SAHN- 
clustering program was plotted in the form of a phenogram by using the tree display graphic (TG).

\section{Results:}

\section{A- Seed Coat Characters (Plate II):}

\section{1- Mimusops laurifolia}

Seeds ovate shaped, pale brown in color The seed coat under SEM observation showed, regulate reticulate ornamentation with raised straight undulate ridges (Plate I\& II).

\section{2- Mimusops elengi}

Seeds ovoid shaped, pale brown in color The SEM examination showed irregular ornamentation, sclariform with fine pored in some rugae, narrow zones of radial tissues (Plate I\& II).

\section{3- Mimusops zeyheri}

Seed ellipsoid shaped, brown in color. Examination of seed surface by SEM showed irregular ornamentation, polygonal clustered cells- tuberculate with closely spaced irregularly shaped tuberless, replicas of freeze on the surface of the membrane (Plate I\& II).

\section{4- Mimusops coffra}

Seed ellipsoid shaped with curled apex, yellow in color. SEM of seed coat showed irregular reticulate ornamentation, peripheral membrane complexes associated with surface present (Plate I\& II). 


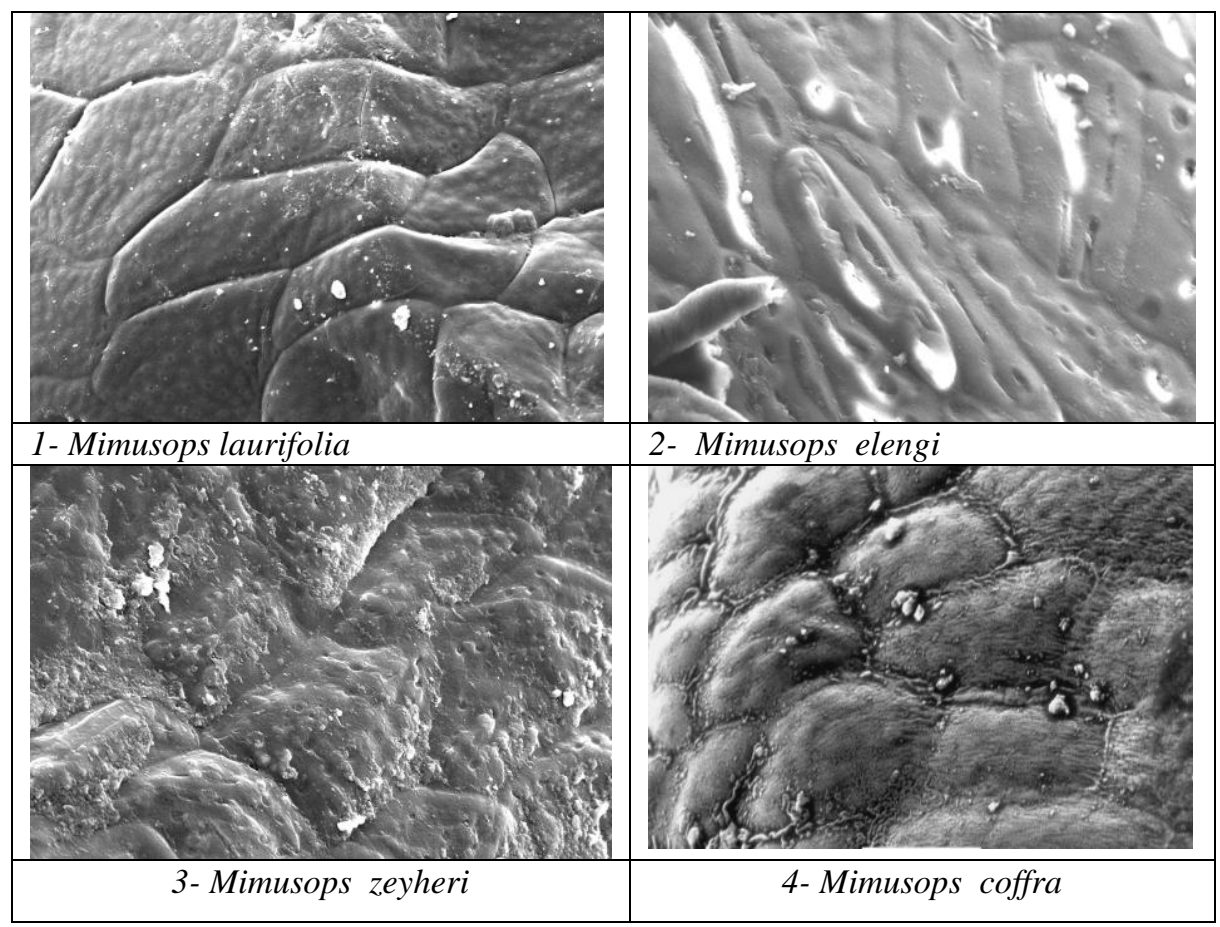

Plate II: SEM Photomicrographs of Seed surface of Mimusops species

\section{B- Electrophoretic Investigations:}

\section{1- Seed Protein Characters:}

The number of bands of protein between the different species are represented in Table (2) and photographed in Plate III. In the studied species of genus Mimusops, there are in total 49 bands have been recorded; 27, 26, 24 and 28 bands have been recorded in M. laurifolia, M. elengi, M. zeyheri and M. coffra, respectively. Band number 1, 4, 29, and 37 are found in all species, 5 bands named 14, 17, 23, 38 and 40 are found in M. laurifolia only. In addition 4 bands of 2, 5,28,45 and 49 are recorded only in $M$. zeyheri. Similarly, two bands 10 and 33 are only found in $M$. elengi. The present studies revealed that M. zeyheri and M. coffra are shared in band number 16. (Table 2, Plate III ).

\section{2- Esterease Isozyme Characters:}

The number of bands of protein between the different species are represented in Table (3) and photographed in Plate IV. In the present investigation, it was found in total 16 protein bands represented as follows; 9 bands have been recorded in 
M. laurifolia, 8 bands have been recorded in M. elengi, 2 bands have been recorded in $M$. zeyheri and 6 bands are represented in M. coffra. The present work showed that, all the studied species are shared in band number 5. Also, 4 bands named 2, 7, 12 and 16 are found in M. laurifolia only. In addition two bands of 3 and 5 are recorded in M. zeyheri. Similarly, three band named 1, 4 and 5 are found in both $M$. laurifolia and M. elengi. (Table 3, Plate IV ).

Table 2: Relative Percentages and Position of Protein Bands of the Total Protein Extracted From the Studied species

\begin{tabular}{|c|c|c|c|c|c|c|c|c|c|c|c|}
\hline \multirow{2}{*}{$\begin{array}{c}\text { Band } \\
\text { No. }\end{array}$} & \multirow{2}{*}{$\begin{array}{l}\text { Relative } \\
\text { Position } \\
\quad(\mathrm{cm})\end{array}$} & \multicolumn{4}{|c|}{ Mimusops Species } & \multirow{2}{*}{$\begin{array}{c}\text { Band } \\
\text { No. }\end{array}$} & \multirow{2}{*}{$\begin{array}{l}\text { Relative } \\
\text { Position } \\
(\mathrm{cm})\end{array}$} & \multicolumn{4}{|c|}{ Mimusops Species } \\
\hline & & 1 & 2 & 3 & 4 & & & 1 & 2 & 3 & 4 \\
\hline 1 & 0.12 & 8.0 & 8.1 & 4.1 & 7.7 & 26 & 6.40 & 6.0 & -- & -- & 8.9 \\
\hline 2 & 0.20 & -- & -- & 2.8 & -- & 27 & 6.60 & -- & 4.5 & -- & 6.8 \\
\hline 3 & 0.25 & -- & 3.5 & -- & 2.9 & 28 & 6.75 & -- & -- & 7.4 & -- \\
\hline 4 & 0.29 & 3.6 & 2.3 & 8.0 & 0.9 & 29 & 7.00 & 2.8 & 6.4 & 1.1 & 3.2 \\
\hline 5 & 0.30 & -- & -- & 2.6 & -- & 30 & 7.21 & 7.6 & -- & -- & 10.0 \\
\hline 6 & 0.34 & 7.5 & 5.00 & -- & 4.2 & 31 & 7.50 & 1.9 & 3.0 & -- & -- \\
\hline 7 & 0.43 & 9.3 & -- & -- & 0.8 & 32 & 7.46 & 2.6 & -- & 7.5 & 2.9 \\
\hline 8 & 0.60 & -- & 3.00 & -- & 2.0 & 33 & 7.60 & -- & 7.5 & -- & --- \\
\hline 9 & 0.65 & 1.8 & -- & 2.1 & -- & 34 & 7.85 & 4.2 & -- & -- & 1.6 \\
\hline 10 & 0.86 & -- & 1.8 & -- & -- & 35 & 8.00 & 6.1 & 5.7 & -- & 1.0 \\
\hline 11 & 0.90 & 7.2 & -- & 2.6 & 1.6 & 36 & 8.17 & 3.2 & 3.1 & -- & 2.5 \\
\hline 12 & 1.00 & -- & -- & 2.5 & -- & 37 & 8.20 & 2.7 & 1.3 & 31.2 & 21.5 \\
\hline 13 & 1.30 & -- & 13.5 & 6.6 & -- & 38 & 8.43 & 2.6 & -- & -- & -- \\
\hline 14 & 1.65 & 5.3 & -- & -- & -- & 39 & 8.63 & -- & 7.8 & 6.4 & 2.1 \\
\hline 15 & 1.87 & -- & 6.9 & 2.9 & -- & 40 & 8.80 & 10.4 & -- & -- & -- \\
\hline 16 & 1.93 & -- & -- & 2.8 & 1.6 & 41 & 8.85 & -- & 4.2 & 6.5 & 1.7 \\
\hline 17 & 2.23 & 4.8 & -- & -- & -- & 42 & 9.01 & --- & 2.1 & -- & -- \\
\hline 18 & 2.50 & -- & 2.4 & -- & 1.2 & 43 & 9.20 & 6.0 & -- & -- & 6.4 \\
\hline 19 & 3.00 & 2.9 & -- & 1.4 & 7.2 & 44 & 9.62 & 2.8 & 4.5 & 7.4 & -- \\
\hline 20 & 3.40 & 5.1 & 5.2 & -- & -- & 45 & 9.84 & -- & -- & 5.6 & -- \\
\hline 21 & 3.60 & 5.4 & -- & 7.8 & 2.1 & 46 & 10.16 & -- & 6.4 & 1.1 & 3.2 \\
\hline 22 & 4.21 & -- & 3.0 & 1.3 & -- & 47 & 10.53 & -- & 7.6 & -- & 10.0 \\
\hline 23 & 4.22 & 2.0 & -- & -- & -- & 48 & 10.59 & 2.6 & 3.0 & -- & -- \\
\hline 24 & 4.60 & -- & 6.4 & -- & 3.8 & 49 & 10.90 & -- & -- & 7.5 & -- \\
\hline 25 & 5.91 & 2.2 & -- & 1.6 & 5.8 & & & & & & \\
\hline
\end{tabular}


Table 3: Relative Percentages and Position of Esterase Isozyme Bands Extracted from the Studied species

\begin{tabular}{|c|c|c|c|c|c|c|c|c|c|c|c|}
\hline \multirow{2}{*}{$\begin{array}{c}\text { Band } \\
\text { No. }\end{array}$} & \multirow{2}{*}{$\begin{array}{c}\text { Relative } \\
\text { Position } \\
(\mathrm{cm})\end{array}$} & \multicolumn{4}{|c|}{ Mimusops Species } & \multirow{2}{*}{$\begin{array}{c}\text { Band } \\
\text { No. }\end{array}$} & \multirow{2}{*}{$\begin{array}{c}\text { Relative } \\
\text { Position } \\
(\mathrm{cm})\end{array}$} & \multicolumn{4}{|c|}{ Mimusops Species } \\
\hline & & 1 & 2 & 3 & 4 & & & 1 & 2 & 3 & 4 \\
\hline 1 & 0.19 & 8.0 & 8.1 & -- & 7.7 & 9 & 1.38 & 3.00 & -- & -- & 6.8 \\
\hline 2 & 0.23 & 5.6 & -- & -- & -- & 10 & 1.45 & 1.8 & -- & -- & -- \\
\hline 3 & 029 & -- & -- & 4.1 & & 11 & 1.90 & -- & 1.8 & -- & -- \\
\hline 4 & 0.31 & 4.6 & 2.3 & -- & 0.9 & 12 & 2.00 & 7.2 & -- & -- & -- \\
\hline 5 & 0.43 & 7.5 & 5.00 & -- & 4.2 & 13 & 2.49 & -- & 6.9 & -- & 6.5 \\
\hline 6 & 0.43 & -- & 3.5 & -- & -- & 14 & 3.02 & -- & 1.8 & -- & -- \\
\hline 7 & 1.20 & 9.3 & -- & 2.6 & -- & 15 & 3.59 & -- & -- & -- & 5.9 \\
\hline 8 & 1.29 & -- & 4.8 & -- & -- & 16 & 3.69 & 2.65 & -- & -- & -- \\
\hline
\end{tabular}

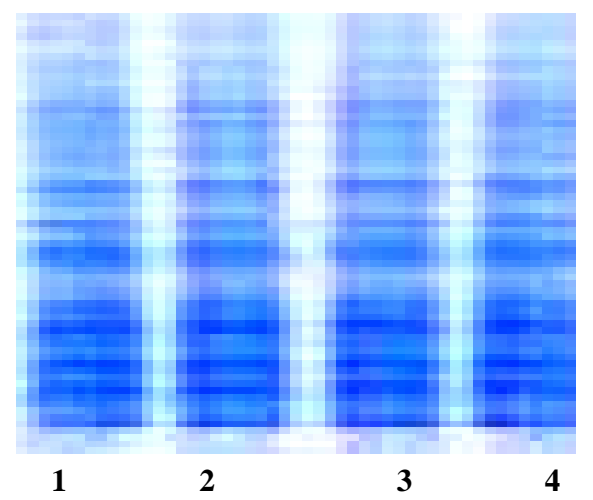

Plate III: SDS-Polyacrylamide Gel Electrophoresis Illustrating Storage Seed Protein of the Studied Species

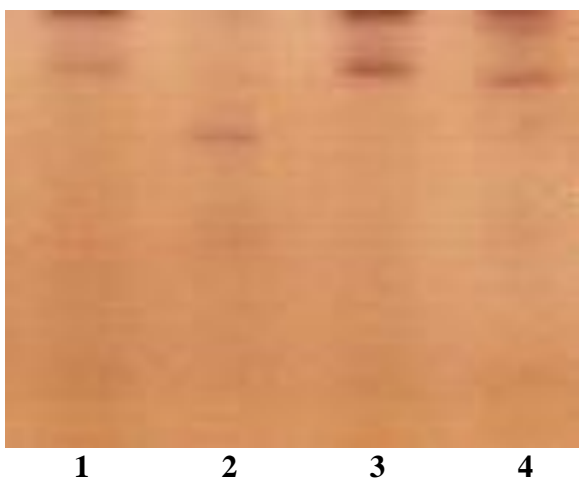

Plate IV: SDS-Polyacrylamide Gel Electrophoresis Illustrating Estereases Isozyme of the Studied Species of the Mimusops 


\section{Numerical Analysis:}

Table 4: Description of the 71 Used Qualitative and Quantitative Characters and Their Codes for Numerical Analysis

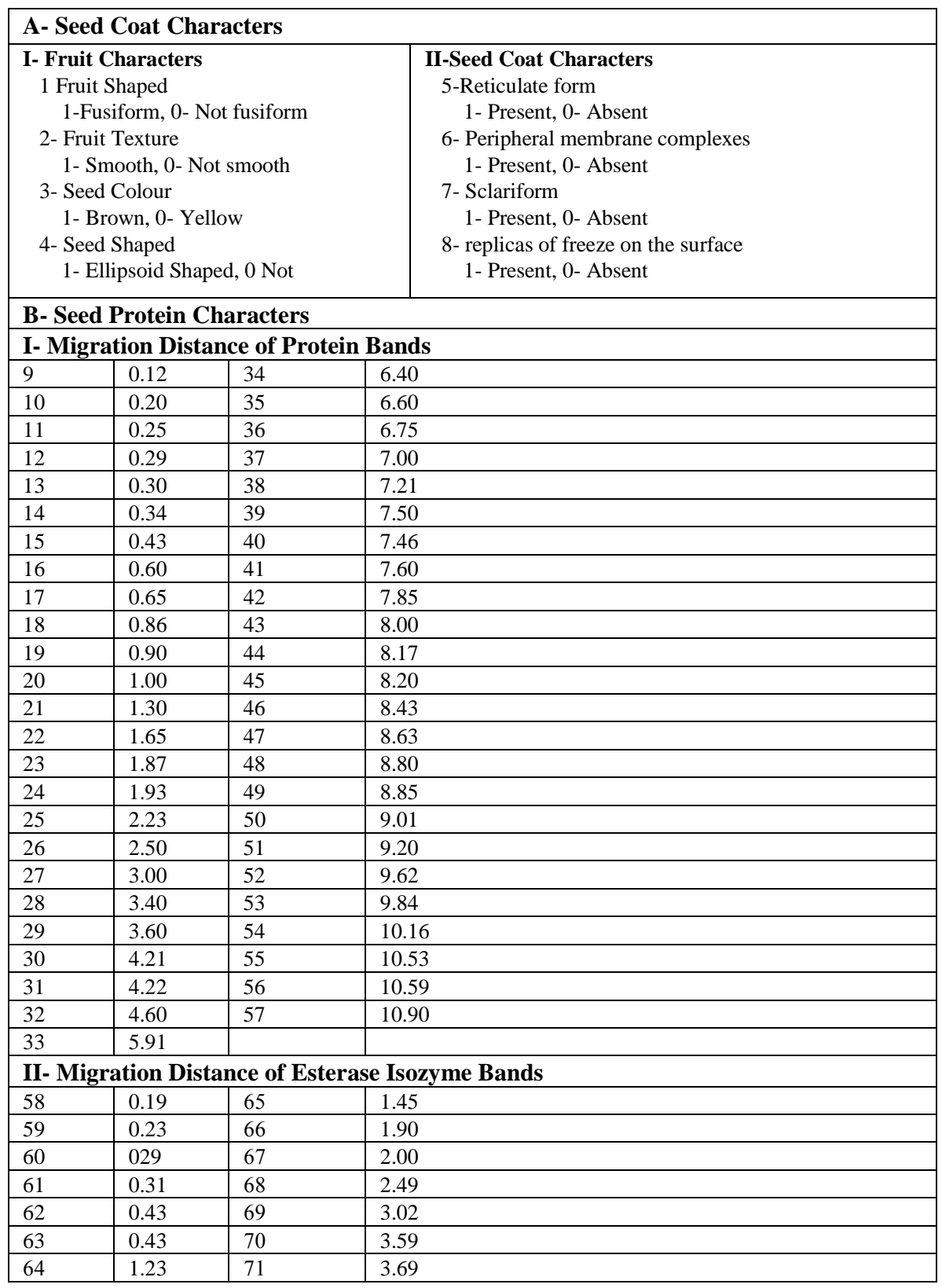


The dendogramm produced from cluster analysis of 71 characters including seed coat scan and seed protein profiles of the studied taxa is given into Fig. 1. Such dendogramm isolates $M$. zeyheri in a separate level at the value of 2.3 linkage distance while clustering the reminder $3 \mathrm{spp}$. into another separate level which separated at the value of 1.7 linkage distance, in which two sub levels are delimited. The first sublevel included M. coffra and M. elengi seem grouped at the levels of 1.3 linkage distance. On the other hand M. laurifolia is separated as the value of 1.7 linkage distance.

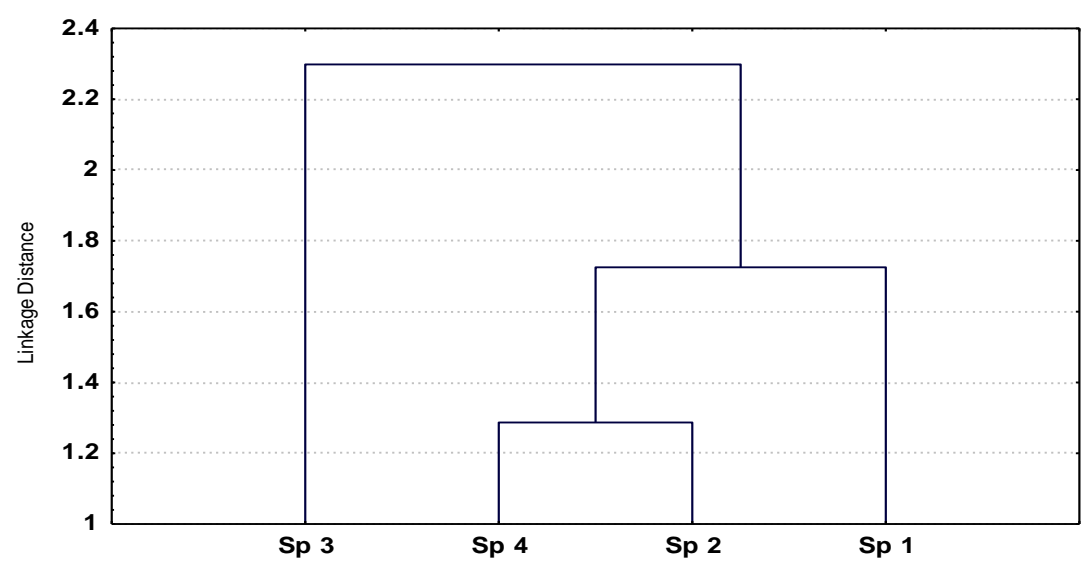

Fig. 1: UPGMA-Dedrogram Based on all Studied Characters (71 Characters) Illustrating Linkage Distances Between the Species

\section{Discussion}

Mimusops plants are trees, or shrubs; evergreen; a shrub or small to mediumsized, usually 10-20 m high, but occasionally reaching up to $25 \mathrm{~m}$ in height. laticiferous. Leaves, alternate (clustered or not); spiral; leathery; petiolate; nonsheathing; simple. Leaves, blades entire; pinnately veined. Mimusops plants have distinctive shape, size and color. The relationships between the studied species are discussed by the numerical analysis and manualed in the light of their seed coat and the molecular characters representing seed protein correlation and esterase isozyme. The ornamentation of the seeds of all the studied species is regulate, the regulation of the seed surface is a common feature at the specific level and hence can be used as an important taxonomic key characteristic of genus. On the other hand, the surface ornamentation in M. zeyheri differs than the rest species of the Mimusops by showing replicas of freeze on the their membrane surface. These results are similar to the results of (Kassem et al., 2004) on studies of 13 taxa of family Myrtaceae in 
Egypt. In the present studies; the Phenogram produced from the cluster analysis of the seed coat, seed protein and esterase isozyme characters (Fig. 1) showed that:

1- Distinguishing the M. laurifolia in a separate level

2- Separation of two species of M. coffra and M. elengi

3- Delimitation of Mimusops zeyheri in a separate level

Seed protein electrophoretic profiles are similar and stable within the four studied species, such protein being little affected by environmental factors (Harborne and Turner, 1984). According to the obtained results of seed protein electrophoretic profiles, there are the first group included M. laurifolia and M. coffra. The second group included M. zeyheri and Mimusops elengi. Consequently, the protein characters do not greatly differentiated between the studied species. Such obtained results in the present work, agreed with results of Podrigues et al., (2004) which carried out on Labramia bojeri seeds, which belong to the Sapotaceae family. Authors noticed that protein bands have shown similar characteristics as molecular masses, determined by gel filtration and native gel; $\mathrm{N}$-terminal sequences presented a difference in their isoelectric points. Because of stability of seed tissue isozyme pattern of plants, the esterase isozyme consider good marker in differentiation between the different species (Crawford and Julian, 1983). So, this enzyme differentiated between a similar species. Where the UPGMA cluster analysis based on the SDS-PAGE profiles separated the M. zeyheri than other studied species. From the results of seed protein and esterase isozyme band number of 2, 5, 28,45 and 49 are found only in this species and has two bands of esterase isozyme named 3 and 5 have been recorded. The results of dendogram (Fig. 1) of four studies species, the investigated characters showed great correlation with the morphological shape. Where the UPGMA cluster analysis based on the SDS-PAGE profiles analysis separated the completely similar species of the genus Mimusops. On the other hand, the present studies revealed that $M$. coffra and M. elengi are correlated in separated subgroup, where the present studies showed that, the two species are shared in 6 protein bands named 3,18,24,35,36 and 47 and shared in 4 esterase bands named $1,4,9$ and 13 .

\section{References}

1. ADRIANSE, A.; KOLP, W., AND ROBBERS, J. E. 1969: Characterization of Phaseolus vulgaris cultivators by their electrophoretic patterns. J. Sci. food Agric. 20: 647-650.

2. BARTHLOTT, W., 1981: Epidermal and seed surface characters of plants, Syst. Applicability and some evolutionary aspects. Nordic. J. Bot.1: 345-355. 
3. BLAKSHEAR, P. J., 1984: Systems of polyacrylamide gel electrophoresis. Methods in enzymol., 104: 237-255.

4. CRAWFORD, D. J. and JULIAN, E. A. ., 1983: Seed protein profiles in the narrow leafed species of chenopodium of thee western U. S. A. Taxonomic value and comparison with distribution of flavonoid compounds. Amer. J. Bot., 63:302-308.

5. GOVAERTS, R. D., FRODIN, T., PENNINGTON, D., 2001: World checklist and bibliography of Sapotaceae. Royal Botanic Gardens, Kew, UK

6. Harborne, J. B. and TURNER, B., 1984: Plant Biosystematics. Chapman and Hall, London.

7. IGOR, V., SWENSON, U., JÉRÔME, M., AND ARNE, A.: 2004: Phylogenetic relationships among New Caledonian Sapotaceae (Ericales). American Journal of Botany. 2005;92:667-673.

8. KASSEM, W, EL-GHAMERY, A., KHALIFA, S., 2004: Cytotaxonomical Studies of some Taxa of Family Myrtaceae in Egypt. Ph. D. thesis, Fac. of Sci., Al-Azhar University Egypt. Pp140.

9. LADIZINSIKY, G. AND HYMOTWITZ, H., 1979: Seed protein electrophoresis in taxonomic and evolutionary studies. Theor. Appl. Genet. 54:145-151.

10. LAEMMLI, U. K., 1970: Cleavage of structural proteins during assembly of the head of Bacteriophage T4. Nature, 227:680-685.

11. NUSRAT, J., WASIM, A. AND ABDUL MALIK., 1995: New Steroidal glycosides from Mimusops elengi. J. Natural Product. Vol. 58, No. 8 PP. 1244-1247, August.

12. RODRIGUES, M., MACHADO, F., MENDES, M., MARTINEZ, D., AND CASSANDRA, B. 2004: Novel protein from Labramia bojeri A. DC. seeds homologue to Kunitz-type trypsin inhibitor with lectin-like properties. Journal of agricultural and food chemistry , vol. 52, pp. 7548-7554.

13. ROHLF, F. J., 1988: NTSYS-PC, numerical Taxonomy and multivariatae analysis systems.Version 1.85. New York, exeter pub., LTD.

14. SHI, Q. AND JACKOWSKI, G., 1998: One-dimensional polyacrylamide gel Electrophoresis. In: Hames, B.D.(eds.) Gel Electrophoresis of Protein. A practical approach. $3^{\text {rd }}$ Edition, Oxford Univerisity Press, Oxford, UK.Pp.1-50.

15. SNEATH, P. H., AND SOKAL, R. R., 1973: Numerical taxonomy. Free Mann. S. Francisco, pp. 753

16. STEGEMANN, H., BRGERMEISTER, W., SHAH, A., FRANCKSEN, H., AND KROGERRECH, E., 1988: Gill electrophoresis between glass plates in polyacrylamide or other gels Righetti Vanoss. Vanderrhoffdes, Els. Evier ( Amsterdam).

17. ZIMNIAK- PRZBYLSKA, Z., BLIXT, S., AND PRZYBYLSKA; J., 1985: Isoenzyme variation inn the genus Psium. Further electrophoretic analysis of amylases from cotyledons of unfermented seeds. Genet. Polon. 26: 303-306. 
الملخص العربي

\section{دراسات مورفولوجية وكيميائية علي بعض الأنواع من جنس الميميزويس المنزرعة في مصر}

وائل طه السيد قاسم ومحمود محمد منصور

من

قسم النبات والميكروبيولوجي - كلية العلوم - جامعة الأزهر (بنين) - مدينة نصر - القاهرة

تمت در اسة اختلافات الثكل الظاهري للبذرة بالإضـافة إلي فحص الأسطح الخارجية بواسطة الميكروسكوب الالكتروني وكذللك المحتوي البروتيني والإنزيمي للبذرة باستخدام طرز التفريد الكهربي للأنو اع المتاحة من جنس الميميزوبس M. laurifolia, M. elengi, M. zeyheri and المنزرعة في مصر. استخلصت 71 صفة ثنائية الاحتمالات من نتائج الدراسـة حلت عدديا باستخدام برنـامج حسـاب المسافة التصنيفية وتثكيل العلاقات في صسورة شـرية فأسفرت عن رسم هيكلي أدي إلي عزل M. zeyheri عن باقي الأنواع الددروسة حيث فصلت هذا النوع عند مستوي تصنيفي مرتفع أمـا بـاقي الأنو اع قتم تميزيها بواسطة البرنامج إلي تحت M. elengi and M. مميز عن النوعين الآخرين و هما M. laurifolia مستوي تصنيفي فيـ 